\title{
Characterization and extraction of volatile compounds from pineapple (Ananas comosus L. Merril) processing residues
}

Lília Calheiros de Oliveira BARRETTO ${ }^{1 \star}$, Jane de Jesus da Silveira MOREIRA ${ }^{1}$, João Antônio Belmino dos SANTOS ${ }^{1}$, Narendra NARAIN ${ }^{1}$, Raquel Anne Ribeiro dos SANTOS ${ }^{1}$

\begin{abstract}
The aim of this study was to extract and identify volatile compounds from pineapple residues generated during concentrated juice processing. Distillates of pineapple residues were obtained using the following techniques: simple hydrodistillation and hydrodistillation by passing nitrogen gas. The volatile compounds present in the distillates were captured by the solidphase microextraction technique. The volatile compounds were identified in a system of high resolution gas chromatography system coupled with mass spectrometry using a polyethylene glycol polar capillary column as stationary phase. The pineapple residues constituted mostly of esters (35\%), followed by ketones (26\%), alcohols (18\%), aldehydes (9\%), acids (3\%) and other compounds (9\%). Odor-active volatile compounds were mainly identified in the distillate obtained using hydrodistillation by passing nitrogen gas, namely decanal, ethyl octanoate, acetic acid, 1 -hexanol, and ketones such as $\gamma$-hexalactone, $\gamma$-octalactone, $\delta$-octalactone, $\gamma$-decalactone, and $\gamma$-dodecalactone. This suggests that the use of an inert gas and lower temperatures helped maintain higher amounts of flavor compounds. These data indicate that pineapple processing residue contained important volatile compounds which can be extracted and used as aroma enhancing products and have high potential for the production of value-added natural essences.
\end{abstract}

Keywords: agro-industrial residues; high resolution gas chromatography; mass spectrometry.

\section{Introduction}

Native to Central and South America, pineapple (Ananas comosus L. Merr.) can be found in tropical regions such as Philippines, Brazil, Costa Rica, Thailand, Hawaii, India, Malaysia and China. However, Brazil and Thailand are the first two positions in the fruit production globally (FOOD..., 2013; ZHENG et al., 2012; MORAIS; SILVA, 2011).

Due to its attractive sweet flavor, pineapple is widely consumed fresh, canned, in processed juices, and as an ingredient in exotic foods (TOKITOMO, 2007). The main pineapple varieties for commercial use are Smooth Cayenne, Singapore Spanish, Red Spanish and Selangor Green (MARCELLINI; DELISA; BOLINI, 2006). In Brazil, the most popular varieties are Perola and Smooth Cayenne (PINHEIRO; VILAS BOAS; LIMA, 2005).

Substantial losses of agricultural products occur across the entire productive chain from harvest to the final consumption. It is estimated that the damages to fruits and vegetables is around $30 \%$ to $40 \%$ because they are highly perishable products (MARTINS; FARIAS, 2002). In addition to posing environmental threat, residues also represent economic and social threat.

Pineapple fruit residues, mainly the rind are generated during the mechanical peeling of the fruit, but they still contain a large amount of pulp which is normally disposed of with other types of residues (SILVA; ZAMBIAZI, 2008). Mostly, the residue is used for animal feed (PRADO et al., 2003) and is not utilized for obtaining other highly aggregated value by-products. Pineapple residue contains high concentrations of vitamins, sugars, fibers, and other constituents which can be used for human consumption (BOTELHO; CONCEIÇÃO; CARVALHO, 2002). Since residue disposal generates several tons of organic material, better economical, scientific, and technical ways to dispose of these residues should be investigated (FERRARI; COLUSSI; AYUB, 2004).

Previous scientific studies have reported the use of pineapple processing residue for animal feeding (LEMOS et al., 2010; CUNHA et al., 2009), develpoment of new products such as cereal bars (PAIVA et al., 2012; FONSECA et al., 2011), cakes (MARTIN et al., 2012) and jellies (SILVA; ZAMBIAZI, 2008), citric acid extraction (IMANDI et al., 2008), phenolic compounds production (CORREIA et al., 2004), bromelain from stem and rind (SILVA et al., 2010), hydrogel from peel cellulose (HU et al., 2010), nanocellulose from leaf fibres (CHERIAN et al., 2010), etc.

The aroma volatile compounds are important properties of fruits and are vital factors to determine the attributes of fresh and processed fruit (WEI et al., 2011). A large number of volatiles have been identified in the pineapple fruit and its derivatives (MORAIS; SILVA, 2011; PINO; QUERIS, 2010; FACUNDO, 2009; ELSS et al., 2005; SPANIER et al., 1998); however, there are no studies available on the extraction and characterization of volatile compounds from pineapple processing residue.

${ }^{1}$ Laboratório de Flavor e Análises Cromatográficas, Programa de Pós-graduação em Ciência e Tecnologia de Alimentos, Universidade Federal de Sergipe - UFS,

Av. Marechal Rondon, s/n, Bairro Jardim Rosa Elze, CEP 49100-000, São Cristóvão, SE, Brasil, e-mail: liliacalheiros@gmail.com

${ }^{*}$ Corresponding author 
The present study aimed to extract volatile compounds from pineapple processing residues using the techniques of simple hydrodistillation and hydrodistillation by passing nitrogen gas. The volatile compounds present in the distillates were captured by solid-phase microextraction (SPME) and indentified by high resolution gas chromatography coupled with mass spectrometry (HRGC-MS).

\section{Materials and methods}

\subsection{Chemicals}

The following reference aroma compounds (purity higher than 98\%) were obtained from Sigma-Aldrich: methyl pentanoate, 2-heptanone, z-ocimene, (Z)-3-hexen-1-ol, ethyl octanoate, nonanal, decanal, benzaldehyde, methyl 3-(methylthio)propanoate, methyl benzoate, ethyl decanoate, $\gamma$-hexalactone, $\gamma$-decalactone, $\delta$-decalactone, methyl hexanoate, ethyl hexanoate, furfural, 1-octanol, methyl decanoate, and 2-phenyl ethanol.

\subsection{Samples}

Pineapple processing residue was obtained from a fruit juice industry located in Estância, in the State of Sergipe, Brazil. The processing residue consisted of rind and fibers left behind during the juice extraction step, in which the fruit was depulped using a depulping machine. The samples were mixed in a blender, placed in low-density polyethylene plastic bags, and stored at $-18^{\circ} \mathrm{C}$. For the extraction of volatile compounds, the samples were defrosted at room temperature and diluted with distilled water (1:3 dilution).

\subsection{Methods}

\section{Simple hydrodistillation}

Volatile compounds were extracted from pineapple processing residue using a condenser by circulating cold water $\left( \pm 2{ }^{\circ} \mathrm{C}\right)$. The experiments were performed in triplicate. Fifty grams of each sample were transferred to a $500 \mathrm{~mL}$ flat-bottom boiling flask, which was coupled to the condenser. The flask was heated on a heating mantle with different extraction conditions: temperatures of $70 ; 80$, and $90^{\circ} \mathrm{C}$ for periods of $5 ; 10 ; 15$, and 30 minutes. The distillates were stored in amber flasks and kept at $-18{ }^{\circ} \mathrm{C}$ until the capture of volatiles by SPME.

\section{Hydrodistillation by passing nitrogen gas}

For volatile compounds extraction using nitrogen gas, $200 \mathrm{~g}$ of pineapple processing residue previously diluted in distilled water (1:3 dilution) was transferred to a $1000 \mathrm{~mL}$ dual neck flat-bottom flask. The vertical neck was coupled to a condenser, and the side neck was coupled to a high purity nitrogen gas inlet tube. The flask was heated on a heating mantle at $60{ }^{\circ} \mathrm{C}$. The gas pressure applied was $0.4 \mathrm{kgf} / \mathrm{cm}^{2}$, and the extractions were performed for $5,10,15$, and 30 minutes. The distillates were stored in amber flasks and kept at $-18^{\circ} \mathrm{C}$ until the capture of volatiles by SPME. Experiments were performed in triplicate.
Solid phase microextraction (SPME)

A manual SPME fiber holder 57330-U and a SPME fiber assembly 50/30 $\mu \mathrm{m}$ Divinylbenzene/Carboxen/ Polydimethylsiloxane (DVB/CAR/PDMS) were purchased from SUPELCO (Bellefonte, PA, USA). The volatile compounds present in the distillates obtained by both hydrodistillation techniques were captured by SPME. Five milliliters of each sample were transferred to a $40 \mathrm{~mL}$ amber glass vial with polypropylene cap and Teflon-faced silicone septa which contained a magnetic stirring bar. The vials were heated in a water bath for 10 minutes at $40^{\circ} \mathrm{C}$ to achieve the equilibrium. The SPME fiber was exposed in the vial headspace for 30 minutes at the same temperature. Later, the holder was taken to the injection part of the HRGC-MS and desorption was performed for 10 minutes.

High resolution gas chromatography-mass spectrometry (HRGC-MS)

The HRGC-MS was performed using a Varian high resolution gas chromatograph (model CP3800) with a polyethylene glycol polar capillary column (CP WAX 52CB; $30 \mathrm{~m}$ $\times 0.25 \mathrm{~mm}$ i.d. $\times 0.25 \mu \mathrm{m}$ film thickness; Varian, Middelburg, The Netherlands) coupled with a mass spectrometer (Saturn 2000R). The following analytical conditions were applied: sample injection $(1 \mu \mathrm{L})$; carrier gas helium $(99.999 \%$ pure) and flow rate $1 \mathrm{~mL} / \mathrm{min}$; splitless mode; injector temperature $220^{\circ} \mathrm{C}$. The oven temperature was programmed starting at $30^{\circ} \mathrm{C}$ ( 3 minutes), later increased at a rate of $2{ }^{\circ} \mathrm{C} / \mathrm{min}$ to $120^{\circ} \mathrm{C}$, which was maintained for 1 minute, followed by the same increase of $2{ }^{\circ} \mathrm{C} / \mathrm{min}$ to $250{ }^{\circ} \mathrm{C}$. Mass spectra were recorded in the electron-impact (EI) mode at $70 \mathrm{eV}$, and the mass range scanned was $\mathrm{m} / \mathrm{z} 33-1000$.

\section{Identification of volatile compounds}

Chromatographic linear retention index (LRI) values were calculated using a homologous series of alkane standards (C8C30) (PolyScience Corp., Niles, WI, EUA; purity 99.997\%), which were analyzed under the same HRGC-MS conditions described above. The identification of the volatile components was performed comparing injections of commercial highly pure standards compounds (purity higher than 98\%) with those of unknown compounds under the same chromatographic conditions. When high-purity chemicals were not available, the comparison was made with retention data and LRI reported in the literature (ADAMS, 2007; KONDJOYAN; BERDAGUÉ, 1996; JENNINGS; SHIBAMOTO, 1980) for tentative identification of the compounds. Comparison between the mass spectra of the National Institute of Standards and Technology (NIST, USA) and that of the unknown compounds spectra was also made for tentative identification (SCHOSSLER et al., 2009).

\section{Statistical analysis}

The data were analyzed using the Statistic 7.0 software version (STATSOFT, 2010). The analyses were performed to identify the relationships between hydrodistillation techniques and the chromatographic profile of the volatile compounds of 
the pineapple residue distillates. The results of the individual experiments were used to calculate the mean values and standard deviations. Analysis of variance (ANOVA) was performed to analyze the results. Significance of differences was defined at the $5 \%$ threshold $(\mathrm{P}<0.05)$.

\section{Results and discussion}

Figure 1 presents the chromatogram of the volatiles captured by SPME obtained from pineapple processing residue treated by simple hydrodistillation at $80{ }^{\circ} \mathrm{C}$ for 5 minutes. These extraction conditions were chosen based on the previous chromatographic data obtained for the other extracts $\left(80^{\circ} \mathrm{C}\right.$ for 10,15 , and 30 minutes; and $90{ }^{\circ} \mathrm{C}$ for all these times), which indicated aroma modification and compounds characterizing sample degradation. For extraction conditions using the lowest temperature $\left(70{ }^{\circ} \mathrm{C}\right)$, although there was no degradation, the peaks were much smaller when compared to those at $80^{\circ} \mathrm{C} / 5$ minutes extraction condition.

The typical chromatogram (Figure 1) shows 35 volatile compounds identified from the headspace of the pineapple processing residue distillate were identified, 29 of them were positively identified based on spectra retention indices data and standards injection, while 6 compounds were tentatively identified based on spectra and retention indices data. The peaks marked in Figure 1 are shown in Table 1. Among the identified components were esters (37\%), alcohols (29\%), aldehydes (9\%), ketones (9\%), acids (6\%), and other compounds (11\%).

The main volatile compounds identified in the distillate of pineapple processing residue obtained by simple hydrodistillation were (Z)-3-hexen-1-ol (35.58\%), methyl octanoate $(26.11 \%)$, 2-phenyl-1-ethanol (13.51\%), 2-methyl-3-buten-2-ol (8.69\%), and 1-hexanol (3.84\%).

Figure 2 shows the chromatogram of volatile extracts obtained from pineapple processing residue treated by hydrodistillation by passing nitrogen gas at $60{ }^{\circ} \mathrm{C}$ for 30 minutes and gas pressure of $0.4 \mathrm{kgf} / \mathrm{cm}^{2}$. The time periods of 5,10 , and 15 minutes presented smaller peaks when compared to those of extraction condition of 30 minutes. Thus the time period of 30 minutes was selected as the best time for this technique. The advantage of hydrodistillation by passing nitrogen gas was the use of lower temperature than that used in the simple hydrodistillation technique. This also avoided sample modification by caramelization. In this method, 34 volatile compounds were identified; 28 of which were positively identified, and 6 were tentatively identified. The peaks observed in Figure 2 are shown in Table 2.

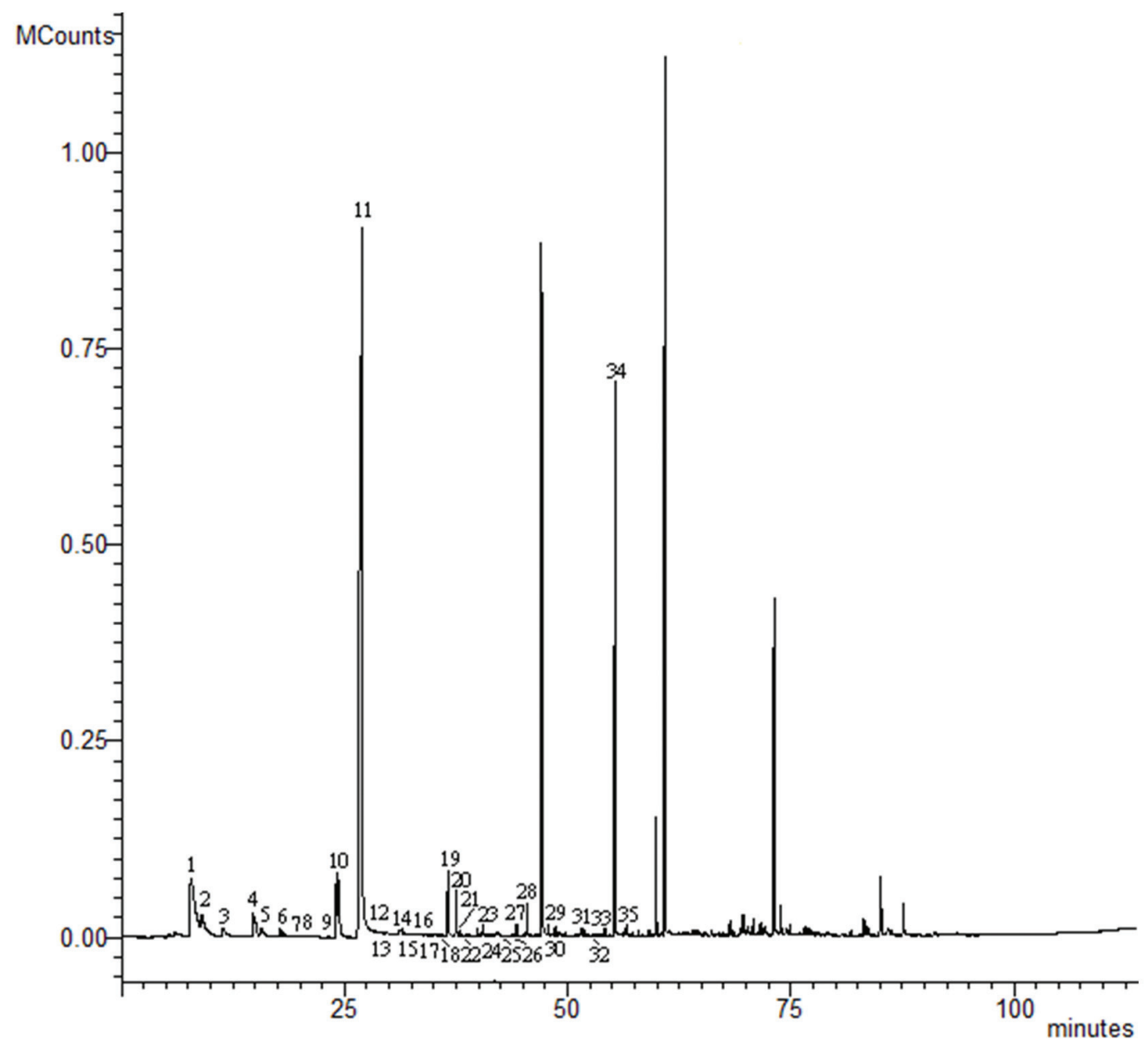

Figure 1. Chromatogram of volatile compounds captured by SPME of pineapple residue distillate previously treated by simple hydrodistillation. 
Barretto et al.

Table 1. Volatile compounds identified in the distillate of pineapple processing residue obtained by simple hydrodistillation.

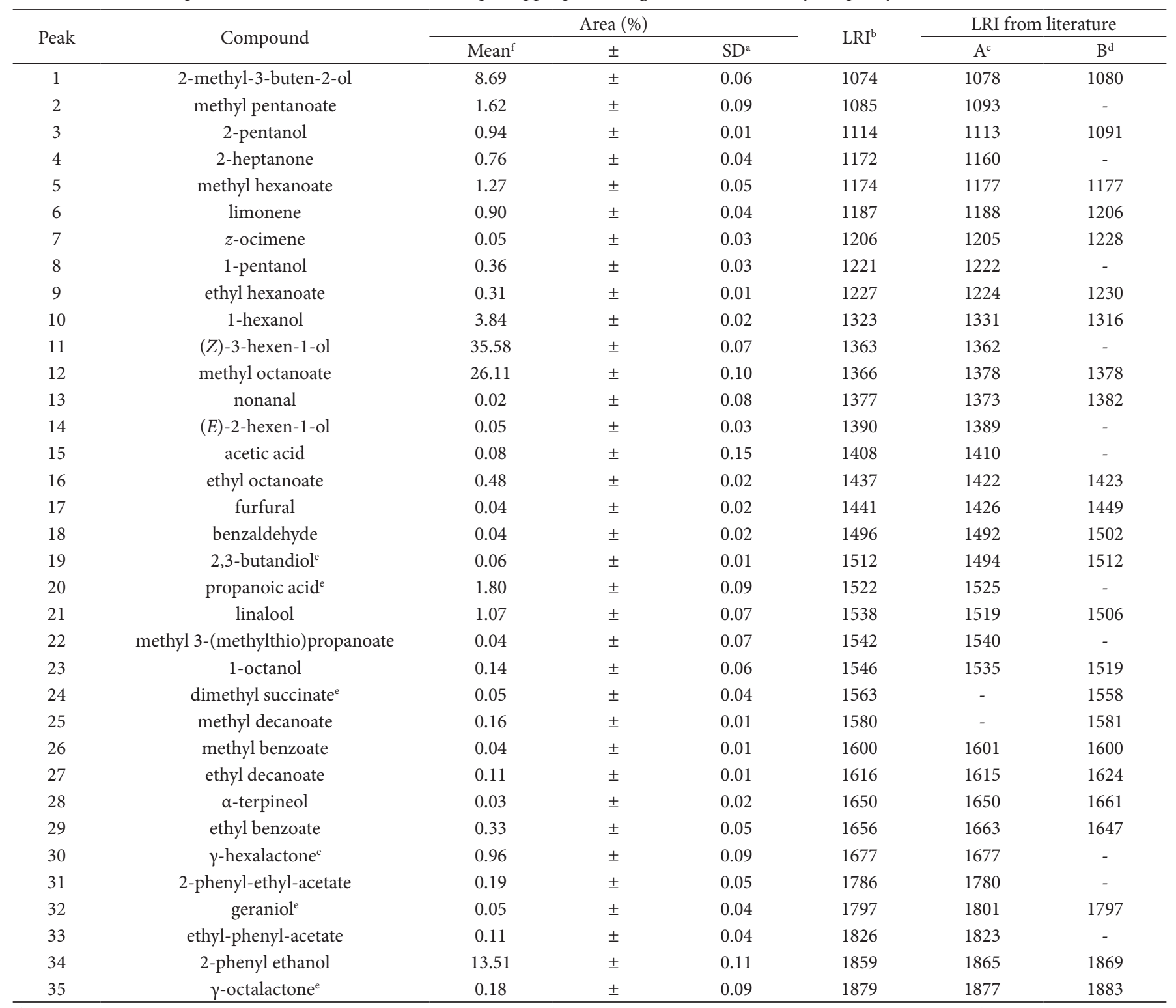

${ }^{\mathrm{f}}$ Mean - mean value; ${ }^{\mathrm{S}} \mathrm{SD}$ - standard deviation (SD/average $\left.\times 100\right)$ of three injections; ${ }^{\mathrm{b}} \mathrm{LRI}-$ linear retention index; ${ }^{\mathrm{c}} \mathrm{A}-$ Kondjoyan and Berdagué (1996); ${ }^{\mathrm{d}} \mathrm{B}-\mathrm{Jennings}$ and Shibamoto

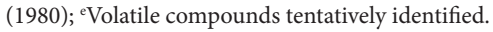

Pineapple processing residue was composed mainly of esters (35\%), followed by ketones (26\%), alcohols (18\%), aldehydes (9\%), acids (3\%), and other compounds (9\%). The major volatile compounds obtained by hydrodistillation by passing nitrogen gas were 1-hexanol (60.19\%), ethyl phenyl-acetate (14.54\%), 2-methyl-3-buten-2-ol (9.33\%), $\gamma$-butyrolactone $(2.08 \%)$, 2-phenyl ethyl-acetate (1.72\%), and ethyl octanoate (1.19\%).

The performance of both methods applied in this study, simple hydrodistillation and hydrodistillation by passing nitrogen gas, were compared. The results showed some compounds with similar area percentage $(\mathrm{P}<0.05)$ such as 2-methyl-3-buten-2-ol (8.69\% and 9.33\%, respectively), methyl pentanoate (1.62\% and $1.06 \%$, respectively), linalool $(1.07 \%$ and $1.08 \%$, respectively), and $\gamma$-hexalactone $(0.96 \%$ and $1.09 \%$, respectively) (Table 3 ).

Wei et al. (2011) identified 44 volatile compounds when characterizing pineapple pulp and core by headspace-solid phase microextraction (HS-SPME) and gas chromatography-mass spectrometry (GC/MS). Some of them are the same as those identified in the present study, in which pineapple residues were characterized: methyl hexanoate, ethyl hexanoate, methyl 3-(methylthio) propanoate, methyl octanoate, ethyl decanoate, a-terpineol, nonanal, and decanal. However, the ones with the highest odor activity values were ethyl hexanoate, nonanal, and decanal, which were also identified in this study.

Morais and Silva (2011) also emphasized that ethyl hexanoate is one of the most important compounds related 


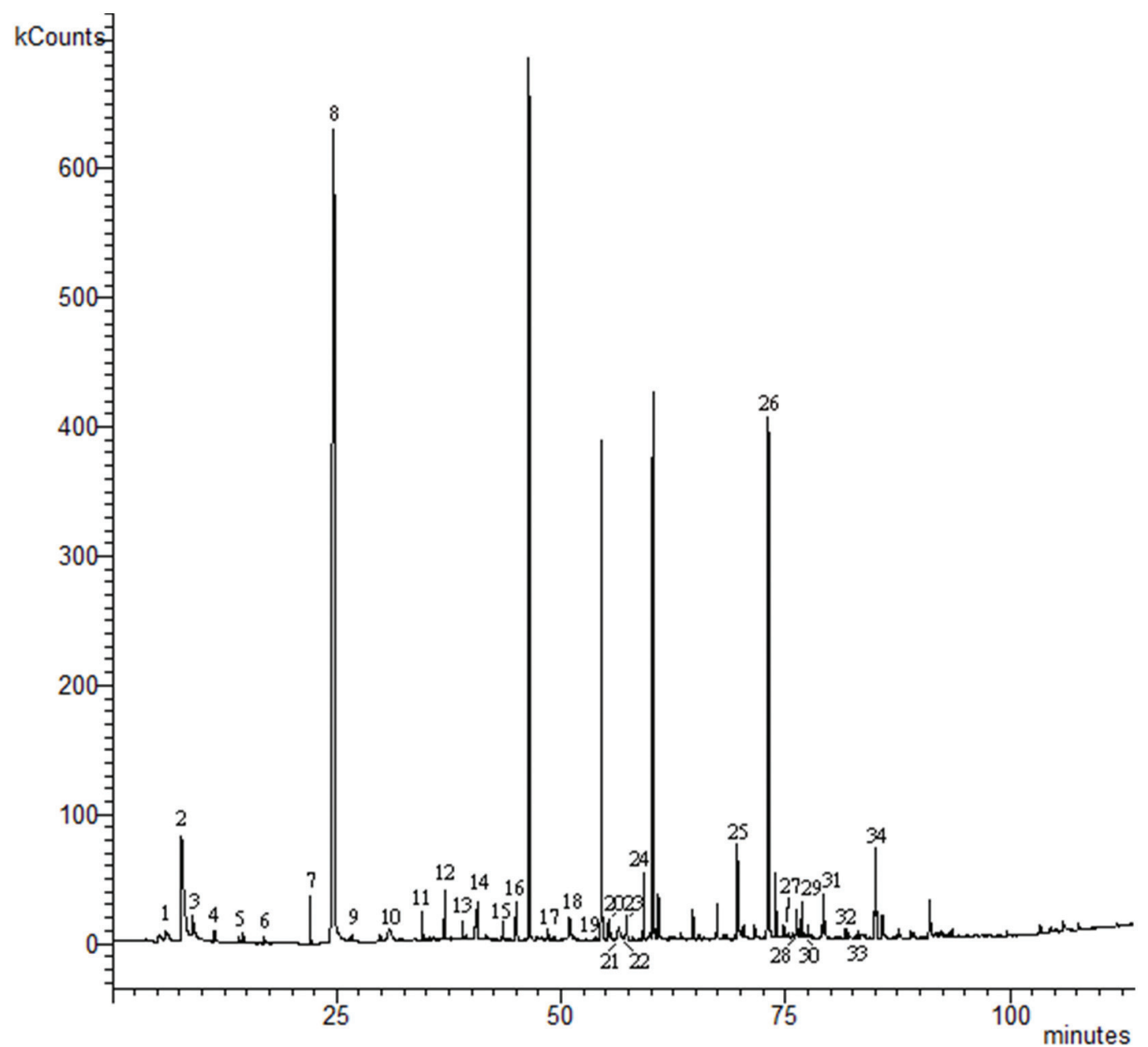

Figure 2. Chromatogram of volatile compounds captured by SPME of pineapple residue distillate previously treated by hydrodistillation by passing nitrogen gas.

to the pineapple flavor. According to Facundo (2009), the compound ethyl hexanoate is related to the aroma note described as 'pineapple'. This compound was also identified in the pineapple processing residue distillate obtained by simple hydrodistillation technique. Ethyl octanoate, 2-heptanone, and $\gamma$-hexalactone were also identified by Facundo (2009) and classified as flavor compounds that have aroma notes such as fruity, floral, citric, herb, and honey. These compounds were identified in the pineapple processing residue distillate obtained by both hydrodistillation techniques in this study.

Tokitomo et al. (2005) prepared an aroma distillate from fresh pineapple using solvent-assisted flavor evaporation and detected 29 odor-active compounds. Some of them were also identified in the distillate of pineapple processing residue obtained by hydrodistillation by passing nitrogen gas such as $\gamma$-octalactone (fruity, coconut-like), $\delta$-octalactone (coconut-like), $\gamma$-decalactone (fruity, sweet, peach-like), and $\gamma$-dodecalactone (fruity, sweet).

Elss et al. (2005) reported the presence of the following volatile compounds when characterizing aroma of fresh pineapple juice and its water phase extracts: 2-methyl-3-buten- 2-ol, methyl pentanoate, butyl acetate, hexanal, 2-pentanol, 1-butanol, ethyl hexanoate, limonene, z-ocimene, linalool, furfural, acetic acid, $\alpha$-terpineol, geraniol, and $\gamma$-octalactone. These compounds were also identified in the distillates obtained in this study.

Spanier et al. (1998) analyzed volatile components present in fresh-cut pineapple and the effect of its storage. Some of these compounds showed important odor activity and were similar to the ones found in this study such as acetic acid, 1-hexanol, and nonanal.

Although ethyl hexanoate is an important pineapple aroma volatile compound (MORAIS; SILVA, 2011), it was not present in high amounts in the pineapple processing residue distillates obtained by both hydrodistillation methods $(0.31 \%$ for simple hydrodistillation and not detected using hydrodistillation by passing nitrogen gas). However, other major volatile compounds were identified in the distillate obtained using hydrodistillation by passing nitrogen gas system, namely, decanal, ethyl octanoate, acetic acid, 1-hexanol, and many ketones such as $\gamma$-hexalactone, $\gamma$-octalactone, $\delta$-octalactone, $\gamma$-decalactone and $\gamma$-dodecalactone (Table 2). This suggests that the use of an inert 
Table 2. Volatile compounds identified in the distillate of pineapple processing residue obtained by hydrodistillation by passing nitrogen gas.

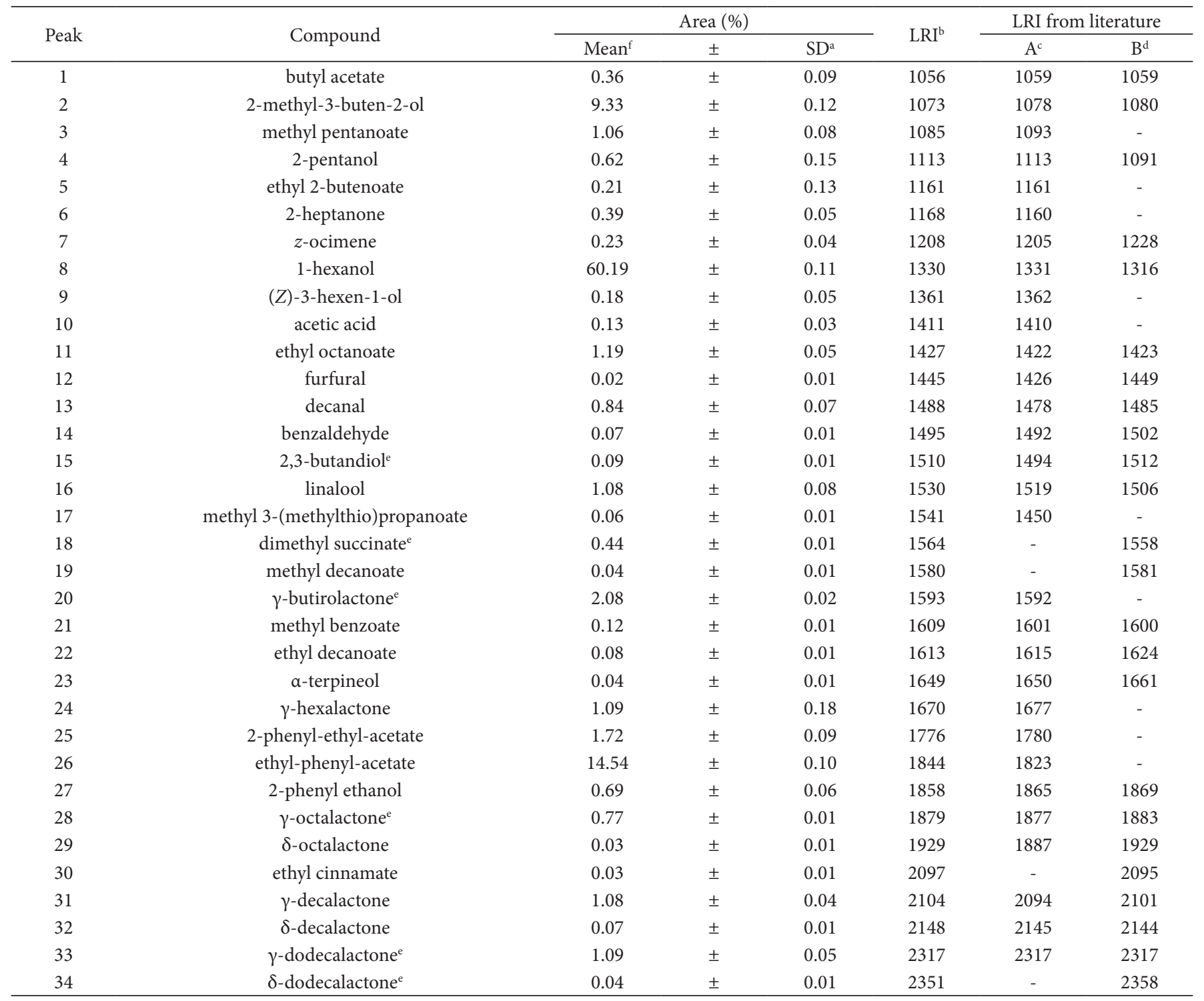

${ }^{\mathrm{f}}$ Mean - mean value; ${ }^{\mathrm{S} D}$ - standard deviation (SD/average x 100) of three injections; ${ }^{\mathrm{b} L R I}$ - linear retention index; ${ }^{\mathrm{c}} \mathrm{A}$ - Kondjoyan and Berdagué (1996); ${ }^{\mathrm{d} B}$ - Jennings and Shibamoto

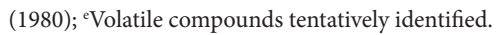

gas and lower temperatures helped maintain higher amounts of odor-active compounds (FACUNDO, 2009; TOKITOMO et al., 2005) than the use of simple hydrodistillation technique. Therefore, the use of nitrogen gas led to more volatile compounds of interest for the flavor industry.

Oliveira et al. (2012) used hydrodistillation techniques for extraction of volatiles from yellow passion fruit residues and obtained aroma compounds similar to the ones present in the fresh fruit. Hydrodistillation by passing nitrogen gas was also preferred when compared with the simple system.

The volatile compounds identified in pineapple processing residue indicate that they have a great potential for the production of aromatic natural essences which could later be added to products such as pineapple juice concentrate enhancing its sensorial quality and increasing competitiveness of this type of product in the global market.

\section{Conclusion}

This study reports for the first time the volatiles profile of pineapple processing residue, which contains a reasonable amount of flavor compounds similar to those present in the fresh fruit juice. The use of an inert gas and lower temperatures helped maintain higher amounts of odor-active compounds such as decanal, ethyl octanoate, acetic acid, 1-hexanol, $\gamma$-hexalactone, $\gamma$-octalactone, $\delta$-octalactone, $\gamma$-decalactone, and $\gamma$-dodecalactone. The results indicate that pineapple processing residue have potential for aromatic essence production. 
Table 3. Comparison between hydrodistillation methods - Common volatile compounds identified in the distillate of pineapple processing residue.

\begin{tabular}{|c|c|c|c|c|}
\hline \multicolumn{2}{|c|}{ Peak } & \multirow{2}{*}{ Compound } & \multicolumn{2}{|c|}{ Area (\%) } \\
\hline SIMP & $\mathrm{N}_{2}$ & & SIMP & $\mathrm{N}_{2}$ \\
\hline 1 & 2 & 2-methyl-3-buten-2-ol & $8.69^{\mathrm{a}}$ & $9.33^{\mathrm{a}}$ \\
\hline 2 & 3 & methyl pentanoate & $1.62^{\mathrm{a}}$ & $1.06^{\mathrm{a}}$ \\
\hline 3 & 4 & 2-pentanol & $0.94^{\mathrm{a}}$ & $0.62^{\mathrm{a}}$ \\
\hline 4 & 6 & 2-heptanone & $0.76^{\mathrm{a}}$ & $0.39^{\mathrm{b}}$ \\
\hline 7 & 7 & z-ocimene & $0.05^{\mathrm{a}}$ & $0.23^{\mathrm{b}}$ \\
\hline 15 & 10 & acetic acid & $0.08^{\mathrm{a}}$ & $0.13^{\mathrm{a}}$ \\
\hline 16 & 11 & ethyl octanoate & $0.48^{\mathrm{a}}$ & $1.19^{\mathrm{b}}$ \\
\hline 17 & 12 & furfural & $0.04^{\mathrm{a}}$ & $0.02^{\mathrm{a}}$ \\
\hline 18 & 14 & benzaldehyde & $0.04^{\mathrm{a}}$ & $0.07^{\mathrm{a}}$ \\
\hline 19 & 15 & 2,3-butandiol & $0.06^{\mathrm{a}}$ & $0.09^{\mathrm{a}}$ \\
\hline 25 & 19 & methyl decanoate & $0.16^{\mathrm{a}}$ & $0.04^{\mathrm{b}}$ \\
\hline 26 & 21 & methyl benzoate & $0.04^{\mathrm{a}}$ & $0.12^{\mathrm{b}}$ \\
\hline 27 & 22 & ethyl decanoate & $0.11^{\mathrm{a}}$ & $0.08^{\mathrm{a}}$ \\
\hline 28 & 23 & $\alpha$-terpineol & $0.03^{\mathrm{a}}$ & $0.04^{\mathrm{a}}$ \\
\hline 30 & 24 & $\gamma$-hexalactone & $0.96^{\mathrm{a}}$ & $1.09^{\mathrm{a}}$ \\
\hline 31 & 25 & 2-phenyl-ethyl-acetate & $0.19^{\mathrm{a}}$ & $1.72^{\mathrm{b}}$ \\
\hline 33 & 26 & ethyl-phenyl-acetate & $0.11^{\mathrm{a}}$ & $14.54^{\mathrm{b}}$ \\
\hline 34 & 27 & 2-phenyl ethanol & $13.51^{\mathrm{a}}$ & $0.69^{\mathrm{b}}$ \\
\hline 35 & 28 & $\gamma$-octalactone & $0.18^{\mathrm{a}}$ & $0.77^{\mathrm{b}}$ \\
\hline
\end{tabular}

SIMP - Simple hydrodistillation; $\mathrm{N}_{2}-$ Hydrodistillation by passing nitrogen gas. Values with different superscript letters $(\mathrm{a}, \mathrm{b})$ are significantly different $(\mathrm{P}<0.05)$.

\section{Acknowledgments}

The authors gratefully acknowledge the Instituto Nacional de Ciência e Tecnologia de Frutos Tropicais/CNPq for the financial support.

\section{References}

ADAMS, R. P. Identification of essential oils components by gas chromatography/mass spectrometry. 4th ed. Carol Stream: Allured, 2007.

BOTELHO, L.; CONCEIÇÃO, A.; CARVALHO, V. D. Caracterização de fibras alimentares da casca e cilindro central do abacaxi 'Smooth Cayenne.' Ciências Agrotécnicas, v. 26, n. 2, p. 362-367, 2002.

CHERIAN, B. M. et al. Isolation of nanocellulose from pineapple leaf fibres by steam explosion. Carbohydrate Polymers, v. 81, n. 3, p. 720-725, 2010. http://dx.doi.org/10.1016/j.carbpol.2010.03.046

CORREIA, R. T. P. et al. Production of phenolic antioxidants by the solid-state bioconversion of pineapple waste mixed with soy flour using Rhizopus oligosporus. Process Biochemistry, v. 39, p. $2167-$ 2172, 2004. http://dx.doi.org/10.1016/j.procbio.2003.11.034

CUNHA, M. G. G. et al. Conservação e utilização do resíduo de abacaxi na alimentação de ovinos no Curimataú Ocidental da Paraíba. Tecnologia \& Ciência Agropecuária, v. 3, n. 3, p. 55-62, 2009.

ELSS, S. et al. Aroma profiles of pineapple fruit (Ananas comosus [L.] Merr.) and pineapple products. LWT - Food Science and Technology, v. 38, p. 263-274, 2005. http://dx.doi.org/10.1016/j. lwt.2004.07.014
FACUNDO, H. V. V. Mudanças no perfil sensorial e de voláteis do suco de abacaxi concentrado durante o processamento. 2009. $82 \mathrm{f}$. Dissertação (Mestrado em Tecnologia de Alimentos)-Faculdade de Engenharia de Alimentos, Universidade Federal do Ceará, Fortaleza, 2009.

FERRARI, R. A.; COLUSSI, F.; AYUB, R. A. Caracterização de subprodutos da industrialização do maracujá - aproveitamento das sementes. Revista Brasileira de Fruticultura, v. 26, n. 1, p. 101-102, 2004. http://dx.doi.org/10.1590/S0100-29452004000100027

FONSECA, R. S. et al. Elaboração de barra de cereais com casca de abacaxi. Archivos Latinoamericanos de Nutrición, v. 61, n. 2, p. 216-223, 2011.

FOOD AND AGRICULTURAL ORGANIZATION OF THE UNITED NATIONS - FAO. FAOSTAT. Food and agricultural commodities production. FAO, 2013.

$\mathrm{HU}$, X. et al. Hydrogels prepared from pineapple peel cellulose using ionic liquid and their characterization and primary sodium salicylate release study. Carbohydrates Polymers, v. 82, n. 1, p. 6268, 2010. http://dx.doi.org/10.1016/j.carbpol.2010.04.023

IMANDI, S. B. et al. Application of statistical experimental designs for the optimization of medium constituents for the production of citric acid from pineapple waste. Bioresource Technology, v. 99 , n. 10 , p. $4445-4450,2008$. http://dx.doi.org/10.1016/j. biortech.2007.08.071

JENNINGS, W.; SHIBAMOTO, T. Qualitative Analysis of Flavor and Fragrance Volatiles by Glass Capillary Gas Chromatography. New York: Acad. Press, 1980. 472 p. 
KONDJOYAN, N.; BERDAGUÉ, J. L. A Compilation of Relative Retention Indices for the Analysis of Aromatic Compounds. Clermont-Ferrand: Laboratoire Flaveur, 1996.

LEMOS, D. M. et al. Composição físico-química de resíduos de abacaxi in natura e desidratado. Tecnologia \& Ciência Agropecuária, v. 4, n. 2, p. 53-56, 2010.

MARCELLINI, P. S.; DELISA, R.; BOLINI, H. M. A. Caracterização sensorial de suco de abacaxi concentrado, reconstituído e adoçado com diferentes edulcorantes e sacarose. Alimentos e Nutrição, v. 17, n. 2, p. 143-150, 2006.

MARTIN, J. G. P. et al. Avaliação sensorial de bolo com resíduo de casca de abacaxi para suplementação do teor de fibras. Revista Brasileira de Produtos Agroindustriais, v. 14, n. 3, p. 281-287, 2012.

MARTINS, C. R.; FARIAS, R. M. Produção de alimentos x desperdício: tipos, causas e como reduzir perdas na produção agrícola - Revisão. Revista da FZVA, v. 9, n. 1, p. 20-32, 2002.

MORAIS, M. M.; SILVA, M. A. Retenção de aroma na secagem em atmosferas normal e modificada: desenvolvimento do sistema de estudo. Ciência e Tecnologia de Alimentos, v. 31, n. 2, p. 295-302, 2011. http://dx.doi.org/10.1590/S0101-20612011000200003

OLIVEIRA, L. C. et al. Caracterização e extração de compostos voláteis de resíduos do processamento de maracujá (Passiflora edulis Sims $\mathrm{f}$. flavicarpa Degener). Ciência Rural, v. 42, n. 12, p. 2280-2287, 2012. http://dx.doi.org/10.1590/S0103-84782012005000103

PAIVA, A. P. et al. Characterization of food bars manufactured with agroindustrial by-products and waste. Ciência e Agrotecnologia, v. 36, n. 3, p. 333-340, 2012. http://dx.doi.org/10.1590/S141370542012000300009

PINHEIRO, A. C. M.; VILAS BOAS, E. V. B.; LIMA, L. C. Influência do $\mathrm{CaCl} 2$ sobre a qualidade pós-colheita do abacaxi cv. Pérola. Ciência e Tecnologia de Alimentos, v. 25, n. 1, p. 32-36, 2005. http://dx.doi. org/10.1590/S0101-20612005000100006

PINO, J. A.; QUERIS, O. Analysis of volatile compounds of pineapple wine using solid-phase microextraction techniques. Food Chemistry, v. 122, n. 4, p. 1241-1246, 2010. http://dx.doi. org/10.1016/j.foodchem.2010.03.033
PRADO, I. N. et al. Níveis de substituição da silagem de milho pela silagem de resíduo industrial de abacaxi sobre o desempenho de bovinos confinados. Revista Brasileira de Zootecnia, v. 32, n. 3, p. 737-744, 2003. http://dx.doi.org/10.1590/S151635982003000300026

SCHOSSLER, P. et al. Volatile compounds of Baccharis punctulata, Baccharis dracunculifolia and Eupatorium laevigatum obtained using solid phase microextraction and hydrodistillation. Journal of the Brazilian Chemical Society, v. 20, n. 2, p. 277-287, 2009. http://dx.doi.org/10.1590/S0103-50532009000200012

SILVA, A. F. R.; ZAMBIAZI, R. C. Aceitabilidade de geléias convencional e light de abacaxi obtidas por resíduos da agroindústria. Boletim do Centro de Pesquisas de Processamento de Alimentos, v. 26, n. 1, p. 1-8, 2008.

SILVA, F. V. et al. Design of automatic control system for the precipitation of bromelain from the extract of pineapple wastes. Ciência e Tecnologia de Alimentos, v. 30, n. 4, p. 1033-1040, 2010. http://dx.doi.org/10.1590/S0101-20612010000400031

SPANIER, A. M. et al. Fresh-cut pineapple (Ananas sp.) flavor. Effect of storage. Developments in Food Science, v. 40, p. 331-343, 1998. http://dx.doi.org/10.1016/S0167-4501(98)80057-5

TOKITOMO, Y. Aroma of pineapple. Foods and Food Ingredients Journal of Japan, v. 212, n. 11, p. 949-956, 2007.

TOKITOMO, Y. et al. Odor-active constituents in fresh pineapple (Ananas comosus [L.] Merr.) by quantitative and sensory evaluation. Bioscience, Biotechnology and Biochemistry, v. 69, n. 7, p. $1323-$ 1330, 2005. http://dx.doi.org/10.1271/bbb.69.1323

WEI, C. et al. Characteristic aroma compounds from different pineapple parts. Molecules, v. 16, n. 6, p. 5104-5112, 2011. http:// dx.doi.org/10.3390/molecules16065104

ZHENG, L. et al. Aroma volatile compounds from two fresh pineapple varieties in China. International Journal of Molecular Sciences, v. 13, n. 6, p. 7383-7392, 2012. http://dx.doi.org http://dx.doi. org/10.3390/ijms13067383 